\title{
Commentary \\ International Federation of Free Journalists: Opposing Communist Propaganda During the Cold War
}

\author{
Martin Nekola \\ Independent Researcher, Czech Republic; E-Mail: marnekola@gmail.com
}

Submitted: 23 May 2017 | Accepted: 31 May 2017 | Published: 27 September 2017

\begin{abstract}
The topic of supranational organizations of East-European émigrés during the Cold War still remains a lesser-known topic. There were a number of anti-Communist organizations between 1948-1989, consisting of former politicians, diplomats, soldiers, lawyers or academics from behind the Iron Curtain. The community of exiled journalists was represented by the International Federation of Free Journalists, officially founded in November 1948 in Paris by delegates from twelve nations. Its membership base soon grew to 1,400 people. The Federation warned the Western public against the injustices, false propaganda and the red terror in Eastern Europe for four decades.
\end{abstract}

\author{
Keywords \\ anti-Communism; Cold War; exile; international; Iron Curtain; journalism
}

\section{Issue}

This commentary is part of the issue "Histories of Collaboration and Dissent: Journalists' Associations Squeezed by Political System Changes", edited by Epp Lauk (University of Jyväskylä, Finland) and Kaarle Nordenstreng (University of Tampere, Finland).

(C) 2017 by the author; licensee Cogitatio (Lisbon, Portugal). This article is licensed under a Creative Commons Attribution 4.0 International License (CC BY).

\section{Introduction}

The story of East European ${ }^{1}$ anti-Communist exiles during the Cold War, for many years a neglected topic, is almost unknown but has recently become the object of historical and political research (Nekola, 2017). The best known political internationals were the International Peasant Union, associating sympathizers of peasant and smallholder parties banned by the Communists, or the Christian Democratic Union of Central Europe created to support Christian democratic policy in exile, as the name suggests. Nevertheless, cooperation was tightening also across various professions in a similar way. Non-Communist union workers established their International Center of Free Trade Unons in Exile in Paris in late 1948 and also the internationals of exiled students, writers, lawyers, and academicians were organized at around the same time. They intended to transfer their activities into the exile and then to become a counterweight to professional unions and central guild organizations back home which had fallen under total Communist control and which had then usurped the sole right to speak on behalf of an entire profession.

The exiled journalists had a much more important task: To counteract reports on developments behind the Iron Curtain from being simply mendacious red propaganda and also to criticize reports from the official mass media and to set the record straight. Nevertheless, little is known about the initiative of exiled journalists from Albania, Bulgaria, Belarussia, Czechoslovakia, Estonia, Hungary, Latvia, Lithuania, Poland, Romania, Ukraine and Yugoslavia to found their international federation and to hold conscientiously the torch of the struggle against false propaganda. They were using their most powerful weapons, the pen and the truth.

\section{Origins of the Federation}

The determination to inform the Western public on what was happening in the East motivated the establishment of the International Federation of Free Journalists of Central and Eastern Europe and Baltic and Balkan Countries

\footnotetext{
1 “East European” in political, not geographical meaning. Émigré groups mentioned in this article cover Central, Eastern and South-Eastern Europe, too.
} 
(IFFJ). Its aims were clear, as stated in the founding Charter: "To oppose any totalitarian doctrines which misrepresent the principles of freedom of the press and tasks and obligations of the press towards nations and towards humanity, and which violate the basic freedom of man and nations" (IFFJ, 1952).

The Federation originated during wartime when cooperation between the Syndicate of Czechoslovak Journalists (Syndikát československých novinárüu) and the Union of Journalists of the Republic of Poland (Zwiqzek Dziennikarzy Rzeczypospolitej Polskiej) developed. Both organizations were based in London and worked closely with the British journalist community to support the war efforts of the Allies. For this same purpose, the Federation of Journalists of Allied and Free Countries was created on 13 December 1941, associating journalists from twelve Allied countries, including the USSR. This federation was dissolved at the foundation congress of the International Organization of Journalists in Copenhagen in June 1946. Neither one of the exile syndicates was allowed to participate. In both Czechoslovakia and Poland a rapid communization of the free press, limiting of civil and political rights and the paths towards totalitarian regime under the hammer and sickle took place. Therefore, many journalists remained in the exile in the British Isles and refused to return. The editor of Czechoslovak desk of BBC, Rudolf Kopecký, cooperated closely with Polish colleagues, above all Antoni Dargas and Bolesław Wierzbiański. Kopecký mentioned in his unpublished memoirs how the nascent IFFJ managed to get a number of prominent figures of the British public and political life, such as leading journalist Malcolm Muggeridge from the Daily Telegraph or the future Prime Minister Harold Macmillan to its first meeting (Kopecký, 1981).

The formation of IFFJ was concluded at the first congress, held on 27-28 November 1948, in Paris, with more than 120 participants representing twelve nations subjugated by the Soviets. ${ }^{2}$ The global membership base soon grew to 1,300 journalists, publishing 350 exile periodicals with a monthly circulation of more than one million copies. The most numerous and influential group were the Poles, with their exile journalist syndicate of 390 members, active in 14 countries.

The founders of IFFJ stated the reasons for its constitution in the preamble:

In the present period of history, when the fate of nations and of individuals depends on the issues undertaken on a world-wide scale, and when an un- precedented crisis threatens our civilisation, based on Christian moral principles, we, delegates of organisations of free journalists from Central and Eastern Europea and Baltic and Balkan countries, think that the time has come to unite the forces of journalistspeople of good will, who respect the proper meaning of words and ideas such as truth, freedom and democracy. (IFFJ, 1952)

As another practical by-product of its wide range of activities, IFFJ attempted to assist exile journalists to find jobs, to market their writings, and to perform tasks in the propaganda struggle for which journalists were particularly suited, or to which they could make a special contribution of talent, experience and knowledge.

The Paris congress had various outcomes including two resolutions towards the United Nations. One called on Western countries for a more serious focus on human rights that were being violated in the Soviet-occupied parts of Europe, and the other accused the International Organization of Journalists of succumbing to Communist propaganda. IFFJ tried to alert the world public about the minimal exchange of information between the free world and the countries behind the Iron Curtain, the expulsion of Western correspondents, the totalitarian control over all communication channels, and the ongoing efforts of Stalinist regimes to subjugate all aspects of free human will. IFFJ congresses usually took place every two years. After the London congress in December 1949, the Federation planned another congress in West Berlin for the end of April 1952, to include invitations to Communist journalists to attend the Congress as a sort of challenge to debate. If refused, this negative could be used as a good propaganda talking point and, if accepted, could turn into a show with great interest to mass media. The initiative, however, was later abandoned out of fear that the Communists might turn the entire congress into another of their propaganda performances. In the end, around 120 free journalists attended the Congress, held in the auditorium of Berlin Technical University, and manifested their determination to defend freedom of the press in Communist regimes. Many guests from American and West-European political, cultural and media circles ensured widespread attention to the event (Piatkowska-Stepniak, 2002).

\section{Against Hammer and Sickle}

The structure of IFFJ more or less mirrored the organizations of a similar nature. The congress/plenum of dele-

\footnotetext{
${ }^{2}$ Each of the journalist groups had its national umbrella organization: Syndicate of Albanian Journalists (regional branches in USA, Great Britain, France and Italy), Association of Free Bulgarian Journalists (USA, Great Britain, Italy, Germany), Syndicate of Romanian Journalists (USA, Great Britain, France, Italy, Germany), Syndicate of Czech Journalists (Great Britain, France, Italy, Germany), Association of Free Czechoslovak Journalists in the USA and Germany (USA, Germany), Union of Slovak Free Journalists and Writers (USA, Great Britain, Germany, France), Estonian Union of Journalists (USA Great Britain, France, Sweden), Association of Hungarian Journalists in Exile (USA, Great Britain, France, Italy, Germany), Union of Latvian Professional Journalists (USA, Great Britain, Sweden, Germany), Association of Lithuanian Journalists (USA, Great Britain, Germany, France), Association of Croatian Journalists (Great Britain, Belgium), Union of Journalists of the Republic of Poland (USA, Great Britain, France, Germany, Italy, Belgium, Sweden, Australia, Argentina), Federation of Democratic Journalists of the Peoples of Yugoslavia (USA, France, Germany), Syndicate of Ukrainian Journalists (Great Britain, France, Germany), Syndicate of White Ruthenian Journalists (Great Britain, France, Germany).
} 
gates of all national associations served as the highest authority of IFFJ. The Board of Directors, composed of two permanent delegates of each national association and of members of the Executive Commitee was in charge of the general management. The nine-headed Executive Committee (Chairman, three Deputy Chairmen, Secretary General, Treasurer and three more members) was directed to hold meetings once a month and to maintain contacts with partner organizations and institutions. In addition, an editorial board came into being to oversee all publications released under the banner of IFFJ: bulletins, booklets. memoranda and, above all, the annual reports of the state of freedom of the press in the world and the IFFJ Bulletin quarterly.

In addition to the London headquarters, a number of regional branches of IFFJ were established. The very important IFFJ-American Regional Union (ARU) opened in New York City in December 1951, led by the Pole Zygmunt Nagórski. He was soon replaced by Mihai Fărcăşanu, head of Romanian desk of Radio Free Europe (RFE). ARU was largely financed by the Free Europe Committee $(\mathrm{FEC})^{3}$ through a monthly contribution of $\$ 500.00$. ARU was, at the time, very important to RFE in gathering and presenting material and information. However, with the development of RFE's own information service, IFFJ's contributions were no longer required and the financial support was reduced in January 1953. Compared to previous years, FEC also minimized funding for other IFFJ branches, publications, congresses, conferences, coloquia, exhibits and other events. Only ARU continued to draw regular contributions from FEC, thanks to the personal friendship of Bolesław Wierzbiański and the FEC President C. D. Jackson (Wierzbiański \& Piatkowka-Stepniak, 2001). As a downside of this connection, occasional doubts appeared, that IFFJ was a Polish monopoly and other national delegations had much smaller powers.

No less important than ARU were the IFFJ offices in Munich, publishing monthly Freie Presse Korrespondenz (Dumitrescu, 1997), in Rome and Stockholm. The Swedish branch administered IFFJ activities in all Scandinavian countries and was headed by Polish-Romanian pair, Norbert Zaba and Georges de Serdici. Beginning in October 1952, it published the monthly Se Upp! with a circulation of up to 10,000 copies. The situation seems to have been more complicated in Paris, where a significant group of exile intellectuals, journalists, artists and writers resided. Union des Journalistes Libres de l'Europe Centrale et Orientale was founded in 1948 under the presidency of Hungarian József Szilágyi and served as an umbrella organization for about 100 journalists. It refused to renounce its independence by merging completely into IFFJ and to become "subordinated" to London headquar- ters. Members of the Union had strong ties to la $R a$ diodiffusion Française, l'Agence France-Presse and other leading information channels in France, and were, therefore, useful partners for IFFJ. Despite personal disputes and controversies over who had the right to nominate delegates for the upcoming international conferences and overseas trips, both organizations cooperated very closely, as a single entity. The press organ of the exile journalists in Paris was the monthly Le Journaliste libre, whose editor-in-chief, Mato Vučetić, had been the director of the information service of the Yugoslav exile government during World War Two.

IFFJ operated its own press agency, the Free European Press Service (FEPS) which specialized in news from behind the Iron Curtain. Originally, IFFJ suggested it would have the role of a regular press agency, serving Western broadcasting and press by supplying current information on the latest developments behind the Iron Curtain. Another proposed medium was an information and research institute, using materials and a "braintrust" from scattered groups of experts. It was hoped that „such an institute would undertake a scientific study of all problems pertaining to the new order in Eastern Europe, and thus render an invaluable service to those seeking to understand the hidden meaning and general purpose of actual events" (IFFJ, 1952). American sponsors didn't show as much enthusiasm toward the idea and IFFJ had to settle for a more modest variant. FEPS was launched with editorial offices in London and New York in June 1950. Funding was assured by putting it on a commercial basis, in other words by regular contracts for the supply of news. FEPS soon started to publish various bulletins, distributed on a subscription basis, such as the Monthly Report on Soviet Affairs.

In October 1949, the Executive Commitee of IFFJ submitted an application for the granting of consultative status with the United Nations and UNESCO. After a long bureaucratic decision-making process, both organizations were approved in 1951. Thus IFFJ became the only "exile group" to be admitted to the UN arena. It was the very first chance for the oppressed nations of Central and Eastern Europe to have the question of their plight openly raised before the important bodies within the UN. Not negligible was another fact: the leading personality of IFFJ, Bolesław Wierzbiański, served as Vice President of the World Conference of Non-Governmental Organizations. Furthermore, IFFJ gradually established regular cooperation with the Organization of American States, the American Newspaper Guild, the Inter-American Federation of Working Newspapermen's Organizations, the Columbia University School of Journalism, the Overseas Press Club, the International Committee on Cultural Exchanges, the International Press Institute, the Asian

\footnotetext{
${ }^{3}$ Free Europe Committee, originally the National Committee for a Free Europe, was an American, anti-Communist organization founded in June 1949 by the USA Department of State. It was charged with finding suitable employment for émigré politicians, journalists and intellectuals from Communist countries in order that, while in exile, they could help prepare for the liberation of their respective countries. The Committee also stood behind a number of anti-Communist campaigns and helped establish well-known institutions such as Radio Free Europe (New York, Munich), Free Europe College (Strasbourg) and the Assembly of Captive European Nations (New York). All these activities, including support of exile national councils and committees, were funded by the CIA. See Kádár Lynn (2013).
} 
Press Associations and Institutes, and, especially, the International Federation of Journalists, based in Brussels, which considered IFFJ a friendly, fraternal organization.

\section{Conclusion}

The bloody repression of the Hungarian uprising by Soviet tanks in the autumn of 1956 completely altered the atmosphere within the exile communities. The hope of return, and of the defeat of the Kremlin's satraps dissipated along with enthusiasm for engaging in exile structures such as IFFJ. The daily stress of feeding families and managing exhaustive employment depressed many capable leaders and limited their work for the organization. Unlike other exile internationals, however, IFFJ maintained its place at center stage during the next decades. It carried out projects in Europe, USA, Latin America, Asia, and Africa, asserting itself by cooperating closely, or in co-sponsoring undertakings, with some of the best known organizations in the field of international journalism. It also experienced a necessary, but difficult generational change. After the retirement of the skilled older journalists, often endowed with experiences from wartime exile, the federation lacked enough capable and committed successors. When Wierzbiański left the chairmanship in 1964 to devote himself to journalistic and editorial work only, IFFJ lost its most prominent spokesperson. From April 1971 on, he began to publish Nowy Dziennik in New York, soon the best-selling newspaper of Polish America.

IFFJ continued to exist in low profile until the fall of the Iron Curtain in 1989. Then, it merged with the International Federation of Journalists.

\section{Acknowledgments}

The author is a member of Edvard Benes Society and he would like to thank its Executive Committee for continued research support.

\section{Conflict of Interests}

The author declares no conflict of interests.

\section{References}

Dumitrescu, V. (1997). O istorie a exilului românesc (1944-1989) [History of Romanian exile (19441989)]. Bucharest: E. V. F.

International Federation of Free Journalists. (1952). International Federation of Free Journalists. London: N. MacNeill \& Co., Press Ltd.

Kádár Lynn, K. (2013). The inauguration of organized political warfare: Cold War organizations sponsored by the National Committee for a Free Europe/Free Europe Committee. Saint Helena: Helena History Press.

Kopecký, R. (1981). Vzpomínky starého novináře [Memoirs of old journalist]. Chicago: University of Chicago.

Nekola, M. (2017). Supranational organizations of the East-European émigrés: A half-forgotten chapter of the Cold War. In P. Jašek (Ed.), Political exile from Central and Eastern Europe: Motives, strategies, activities and perceptions of East and West, 1945-1989 (pp. 422-444). Bratislava: Nation's Memory Institute.

Piatkowska-Stepniak, W. (2002). Nowy Dziennik w Nowym Świecie [New Journal in a new world]. Opole: Uniwersytet Opolski.

Wierzbiański, B., \& Stepniak-Piatkowska, B. (2001). Dziennikarze polscy na emigracji [Polish journalists in exile]. Opole: Uniwersytet Opolski.

\section{About the Author}

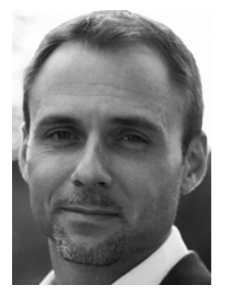

Martin Nekola, PhD, received his doctorate in political science at the Charles University in Prague. His research is focused on non-democratic regimes, the era of Communism, and the East-European antiCommunist exiles during the Cold War. He is the author of two hundred articles and has published eight books, the most recent of which are Petr Zenkl: Politik a člověk (Petr Zenkl: Politician and Man, 2014), Krvavé století (Bloody Century, 2015) and České Chicago (Czech Chicago, 2017). 